\title{
PENGARUH POLA MAKAN TERHADAP KADAR KOLESTEROL TOTAL
}

\section{The Influence of Diet to Total Cholesterol Levels}

\author{
Alodiea Yoeantafara ${ }^{1}$, Santi Martini ${ }^{2}$ \\ ${ }^{1}$ Mahasiswa Fakultas Kesehatan Masyarakat Universitas Airlangga \\ ${ }^{2}$ Departemen Epidemiologi Fakultas Kesehatan Masyarakat Universitas Airlangga \\ (alodiieafara09@yahoo.co.id, santi-m@fkm.unair.ac.id)
}

\begin{abstract}
ABSTRAK
Kadar kolesterol total di dalam darah sangat berpengaruh terhadap pembentukan plak pada dinding pembuluh darah. Kadar kolesterol yang melebihi batas normal akan memicu terjadinya proses aterosklerosis. Aterosklerosis merupakan manifestasi klinis dari Penyakit Jantung Koroner. Tujuan penelitian ini adalah menganalisis hubungan antara pola makan dengan kadar kolesterol total. Penelitian ini merupakan penelitian observasional analitik, menggunakan desain penelitian case control. Sampel penelitian ini sebesar 56 orang yang terdiri dari 28 kasus dan 28 kontrol. Sampel diambil secara acak menggunakan simple random sampling. Analisis data menggunakan uji statistik dan perhitungan OR dengan Epi Info. Hasil penelitian besar risiko kadar kolesterol total adalah usia $(\mathrm{p}=1,00 ; \mathrm{OR}=1,2 ; 95 \% \mathrm{CI}=0,36<\mathrm{OR}<3,92)$, pola makan tinggi lemak $(\mathrm{p}=0,285 ; \mathrm{OR}=2,06 ; 95 \% \mathrm{CI}=0,7<\mathrm{OR}<5,98)$, pola makan tinggi serat $(\mathrm{p}=0,030 ; \mathrm{OR}=4 ; 95 \% \mathrm{CI}=1,28<\mathrm{OR}<12,4)$. Kesimpulan dari penelitian ini adalah pola makan tinggi serat memiliki OR yang bermakna sedangkan usia dan pola makan tinggi lemak tidak signifikan. Sebaiknya diberikan tambahan informasi yang diberikan kepada masyarakat peduli tentang faktor-faktor risiko tingkat kolesterol total yang mencakup makan pola diet tinggi lemak, rendah serat.
\end{abstract}

Kata kunci: Pola makan tinggi serat, pola makan tinggi lemak, kadar kolesterol total

\section{ABSTRACT}

Levels of total cholesterol in the blood are very influential towards the formation of plaque in blood vessel walls.. Cholesterol levels that exceeded the normal limit will trigger the onset of the process of atherosclerosis, atherosclerosis is the clinical manifestation of coronary heart disease. The purpose of this research was to analyze the relationship between food pattern and cigarette smoke exposure with total cholesterol levels. The definition of food pattern was diet in high fat and high fiber. This research was an observational analytic study, with case-control design. The sample were 56 persons that consisting 28 cases and 28 controls. Sampel taken by simple random sampling. The results of this research were the risk of total cholesterol levels was age ( $p=1,00 ; O R=1,2 ; 95 \%$ $C I=0,36<O R<3,92)$, hight fat diet $(p=0,285 ; O R=2,06 ; 95 \% C I=0,7<O R<5,98)$, high fiber diet $(p=0,030$ $O R=4 ; 95 \% C I=1,28<O R<12,4)$. The conclusion of this research was a diet high in fiber have OR that meaningful while age and high-fat diet have no significant. We recommended additional information given to the public to care about the risk factors of total cholesterol levels which includes eating pattern high-fat, high-fiber diet.

Keywords: Diet in high fiber, diet in high fat, levels of total cholesterol 


\section{PENDAHULUAN}

Penyakit Tidak Menular (PTM) merupakan salah satu masalah kesehatan yang telah menjadi perhatian nasional maupun global. Morbiditas dan Mortalitas PTM semakin meningkat di Indonesia. Data kematian menurut World Health Organization (WHO) menunjukkan bahwa dari 57 juta kematian di dunia pada tahun 2008, sebanyak 36 juta disebabkan oleh PTM. Penyakit kardiovaskular merupakan PTM penyebab kematian terbesar yaitu sebesar 39\%. Kematian akibat PTM akan terus meningkat di seluruh dunia. Peningkatan terbesar akan terjadi di negara menengah dan miskin. Sebesar $70 \%$ dari populasi global akan meninggal akibat PTM seperti jantung, stroke, diabetes mellitus, kanker. ${ }^{1}$

Transisi epidemiologi penyakit menular menjadi penyakit tidak meular akan terlihat jelas pada tahun 2030. Jumlah kesakitan akibat penyakit tidak menular dan kecelakaan akan meningkat, sedangkan penyakit menular akan menurun. Peningkatan kejadian PTM ini berhubungan dengan faktor risiko akibat adanya perubahan gaya hidup seiring dengan perkembangan yang semakin moderen, pertumbuhan populasi dan peningkatan usia harapan hidup. ${ }^{2}$

Tingginya kadar kolesterol di dalam darah merupakan permasalahan yang serius karena merupakan salah satu faktor risiko dari berbagai macam penyakit tidak menular seperti jantung, stroke, dan diabetes mellitus. Bedasarkan penelitian-penelitian yang telah dilakukan risiko terjadinya ateroklerosis yang merupakan penyebab PJK akan meningkat apabila kadar kolesterol total di dalam darah melebihi batas normal. ${ }^{3}$

Kadar kolesterol yang berlebih dalam darah akan akan mudah melekat pada dinding sebelah dalam pembuluh darah. LDL yang berlebih melalui proses oksidasi akan membentuk gumpalan yang jika gumpalan semakin membesar akan membentuk benjolan yang akan mengakibatkan penyempitan saluran pembuluh darah. Proses ini biasanya disebut dengan atheroklerosis. ${ }^{3}$

Prevalensi hiperkolesterolemia di Indonesia menurut Survei Kesehatan Rumah Tangga (SKRT) tahun 2004 pada kelompok usia 25-34 tahun adalah 9,3\% dan meningkat seiring betambahnya usia pada kelompok usia 53-64 tahun sebesar 15,5\%.Untuk prevalensi hiperkolesterolemia di Indonesia sebesar 1,5\% pada laki-laki dan 2,2 pada perempuan. ${ }^{4}$ Hasil Riskesdas tahun 2013 proporsi penduduk Indonesia dengan kadar kolesterol di atas normal lebih tinggi pada perempuan yaitu sebesar 39,6\% jika dibandingkan dengan laki-laki sebesar 30\%. Beberapa faktor yang memengaruhi kadar kolesterol total adalah pola makan tinggi serat, pola makan tinggi lemak, kebiasaan merokok, jenis kelamin, obesitas dan aktifitas fisik. ${ }^{3}$

Konsumsi serat dapat membantu menurunkan absorpsi lemak dan kolesterol di dalam darah. Beberapa penelitian menunjukkan bahwa diet serat dengan cara mengkonsumsi makanan tinggi kacang polong, termasuk kacang merah, mampu menurunkan kadar kolesterol di dalam darah hingga $10 \%$ pada penderita hiperkolesterolemia. Selain itu serat larut air yang difermentasi dalam usus besar akan menghasilkan asam-asam lemak rantai pendek yang dapat menghabiskan sintesis kolesterol hati. ${ }^{5}$

Seringnya mengkonsumsi makanan tinggi lemak menjadi penyebab utama meningkatnya kadar kolesterol total di dalam darah. Hasil penelitian Sulastri menunjukkan kadar kolesterol akan berkurang seiring dengan rendahnya asupan makanan berlemak. ${ }^{6}$ Kadar kolesterol yang melebihi batas normal akan memicu terjadinya proses ateros- klerosis. Aterosklerosis merupakan proses terjadinya penyempitan pembuluh darah oleh lemak. Aterosklerosis merupakan manifestasi klinis dari penyakit jantung. Penelitian ini bertujuan mengetahui hubungan pola makan tinggi lemak dan serat dengan kadar kolesterol total.

\section{BAHAN DAN METODE}

Jenis penelitian yang digunakan adalah observasional yang bersifat analitik karena ingin menganalisis hubungan antar variabel. Desain yang digunakan dalam penelitian ini adalah kasus kontrol. Populasi kasus dalam penelitian ini adalah seluruh pasien yang memiliki kadar kolesterol total tinggi, sedangkan populasi kontrol adalah seluruh pasien yang memiliki kadar kolesterol normal. Untuk menentukan populasi penelitian dan sampel penelitian terdapat kriteria inklusi dan ekslusi. Kriteria inklusi yang dierapkan adalah: Pasien berumur $\geq 40$ tahun. Sedangkan kriteria ekslusi yang diterapkan adalah pasien dengan obesitas, pasien yang melakukan olahraga scara rutin 5 
hari dalam seminggu selama 30 menit.. Bedasarkan perhitungan sampel untuk desain penelitian kasus kontrol, didapatkan jumlah sampel sebanyak 56 responden. $^{7}$ Dengan jumlah sampel kasus sebanyak 28 responden dan untuk sampel kontrol sebanyak 28 responden.

$$
n=\frac{\left(Z_{1-\propto / 2} \sqrt{P Q}+Z_{1-\beta} \sqrt{P_{1} Q+P_{2} Q}\right)^{2}}{\left(P_{1-} P_{2}\right)^{2}}
$$

Cara yang digunakan untuk pengambilan sampel adalah menggunakan metode simple random sampling. Pengambilan sampel dilakukan menggunakan nomor undian hingga mendapat-kan jumlah yang sesuai dengan besar sampel yang dibutuhkan dari masing-masing kelompok. Tempat penelitian dilakukan di Puskesmas Mulyorejo dan rumah masing-masing responden. Waktu penelitian bulan Mei-Juli 2017. Sumber data yang digunakan dalam penelitian ini adalah data primer dan sekunder. Data primer diperoleh melalui wa- wancara kepada responden dengan menggunakan kuesioner, untuk data sekunder diperoleh dari data hasil rekam medik responden di Puskesmas Mulyorejo. Kuesioner yang digunakan dalam penelitian ini adalah FFQ (Food Frequency Questionnaire). FFQ digunakan untuk mengukur frekuensi pola makan tinggi lemak dan serat responden. Pola makan responden tinggi lemak dan serat dikategorikan sering jika hasil skor pada Food Frequency Questionnaire $\geq$ mean, sedangkan dikategorikan jarang jika skor $<$ mean. Analisis data dilakukan menggunakan software SPSS dan Epi Info. Untuk melihat besar hubungan pola makan dan paparan asap rokok dengan kadar kolesterol total menggunakan uji Chi-square dengan tingkat kemaknaan 0,05 . Apabila persyaratan tabel $2 \times 2$ memenuhi maka hasil uji chi-square yang dibaca adalah continuity correction, tetapi apabila tabel $2 \times 2$ tidak memenuhi syarat yang dibaca adalah Fisher's Exact Test. Untuk menghitung besar risiko menggunakan nilai Odd Ratio (OR) pada 95\% Confidence Interval (CI) pada statcalc Epi Info.

\section{HASIL}

Hasil penelitian di Puskesmas Mulyorejo pada bulan Juli tahun 2017 menununjukkan bahwa karakteristik responden bedasarkan usia pada sampel penelitian ini, sebagian besar responden beru-
Tabel 1. Variabel Penelitian

\begin{tabular}{lcc}
\hline Variabel & $\mathbf{n}=\mathbf{5 6}$ & $\mathbf{\%}$ \\
\hline Pola Makan Tinggi Lemak & & \\
Sering & 29 & 51,8 \\
Jarang & 27 & 48,2 \\
Pola Makan Tinggi Serat & & \\
$\quad$ Sering & 33 & 58,9 \\
Jarang & 23 & 41,1 \\
\hline
\end{tabular}

Sumber: Data Primer, 2017

sia $>45$ sampai 75 tahun $(73,2 \%)$. Sisanya sebesar $26,8 \%$ responden berusia $40-45$ tahun. Pola makan responden tinggi lemak dikategorikan sering jika hasil skor pada Food Frequency Questionnaire $\geq$ mean $(1,47)$, sedangkan dikategorikan jarang jika skor $<$ mean. Sebagian besar responden memiliki pola makan tinggi lemak dengan kategori sering $(51,8 \%)$, untuk persentase kategori jarang sebesar $48,2 \%$. Pola makan responden tinggi serat dikategorikan sering jika hasil skor pada Food Frequency Questionnaire $\geq$ mean $(2,37)$, sedangkan dikategorikan jarang jika skor $<$ mean. Sebagian besar responden memiliki pola makan tinggi serat dengan kategori jarang $(58,9 \%)$, untuk persentase kategori sering sebesar 41,1\% (Tabel 1).

Hubungan variabel usia dengan kadar kolesterol total menunjukkan sebagian besar responden yang memiliki kadar kolesterol total tinggi adalah kelompok usia $\geq 45$ tahun (75\%). Bedasarkan hasil uji statistik diperoleh hasil uji chi-square dengan nilai $\mathrm{p}=1 \quad(\mathrm{p}>0,05)$ berarti tidak ada hubungan antara usia dengan kadar kolesterol total. Perhitungan besar risiko kelompok yang berada pada rentang usia tertua $>45$ tahun dan usia termuda $\leq 45$ tahun, diperoleh OR sebesar 1,2 dengan nilai $95 \%$ CI sebesar $0,36<\mathrm{OR}<3,92$. Nilai OR melewati angka 1 menunjukkan bahwa nilai OR tidak signifikan secara statistik sehingga tidak terdapat perbedaan risiko yang bermakna antara kelompok responden yang berusia $>45$ tahun dan $\leq 45$ tahun (Tabel 2).

Hubungan variabel pola makan tinggi lemak dengan kadar kolesterol total menunjukkan sebagian besar responden yang memiliki kadar kolesterol total tinggi adalah yang memiliki pola makan tinggi lemak dalam kategori sering $(60,71 \%)$. Berdasarkan hasil uji statistik diperoleh chi-square dengan nilai $\mathrm{p}=0,285(\mathrm{p}>0,05)$ berarti tidak ada hubungan antara pola makan tinggi 
Tabel 2. Fakto yang Berhubungan dengan Kadar Kolesterol Total

\begin{tabular}{|c|c|c|c|c|c|c|}
\hline \multirow{3}{*}{ Variabel } & \multicolumn{4}{|c|}{ Kadar Kolesterol Tinggi } & \multirow{3}{*}{$\mathbf{p}$} & \multirow{3}{*}{$\begin{array}{c}\text { OR } \\
(95 \% \mathrm{CI})\end{array}$} \\
\hline & \multicolumn{2}{|c|}{ Tinggi } & \multicolumn{2}{|c|}{ Normal } & & \\
\hline & $\mathbf{n}$ & $\%$ & $\mathbf{n}$ & $\%$ & & \\
\hline \multicolumn{7}{|l|}{ Usia (tahun) } \\
\hline$>45-75$ & 21 & 75 & 20 & 71,43 & 1,000 & 1,2 \\
\hline $40-45$ & 7 & 25 & 8 & 28,57 & & $0,36<\mathrm{OR}<3,92$ \\
\hline \multicolumn{7}{|c|}{ Pola Makan Tinggi Lemak } \\
\hline Sering & 17 & 60,71 & 12 & 42,86 & 0,285 & 2,06 \\
\hline Jarang & 11 & 39,29 & 16 & 57,14 & & $0,7<\mathrm{OR}<5,98$ \\
\hline \multicolumn{7}{|c|}{ Pola Makan Tinggi Serat } \\
\hline Jarang & 21 & 75 & 12 & 42,86 & 0,030 & 4 \\
\hline Sering & 7 & 25 & 16 & 57,14 & & $1,28<\mathrm{OR}<12,4$ \\
\hline
\end{tabular}

Sumber: Data Primer, 2017

lemak dengan kadar kolesterol total. Untuk hasil perhitungan besar risiko diperoleh OR sebesar 2,06 dengan nilai $95 \%$ CI sebesar $0,7<\mathrm{OR}<5,98$. Nilai OR melewati angka 1 menunjukkan bahwa nilai OR tidak signifikan secara statistik sehingga tidak terdapat perbedaan risiko yang bermakna antara kelompok responden yang memiliki pola makan tinggi lemak dalam kategori sering dengan kelompok responden yang memiliki pola makan tinggi lemak dalam kategori jarang (Tabel 2).

Hubungan variabel antara pola makan tinggi serat dengan kadar kolesterol total menunjukkan sebagian besar responden yang memiliki kadar kolesterol total tinggi adalah yang memiliki pola makan tinggi serat dalam kategori jarang (75\%). Bedasarkan hasil uji statistik chi-square diperoleh nilai $\mathrm{p}=0,030(\mathrm{p}<\alpha)$ berarti ada hubungan antara pola makan tinggi serat dengan kadar kolesterol total. Untuk hasil perhitungan besar risiko diperoleh OR sebesar 4 dengan nilai 95\% CI sebesar $1,28<\mathrm{OR}<12,4$. Nilai OR tidak melewati angka 1 menunjukkan bahwa nilai OR signifikan secara statistik sehingga terdapat perbedaan risiko yang bermakna antara kelompok responden yang memiliki pola makan tinggi serat dalam kategori sering dengan kelompok responden yang memiliki pola makan tinggi serat dalam kategori jarang. Sedangkan nilai OR menujukkan bahwa responden yang memiliki pola makan tinggi serat dalam kategori jarang berisiko 4 kali mempunyai kadar kolesterol tinggi dibandingkan dengan responden yang memiliki pola makan tinggi serat dalam kategori sering (Tabel 2).

\section{PEMBAHASAN}

Bedasarkan penelitian yang telah dilakukan, didapatkan hasil bahwa tidak ada hubungan antara usia dengan kadar kolesterol total $(p>0,05)$. Banyak peneliti menyimpulkan bahwa semakin bertambahnya usia kemampuan reseptor LDL akan menurun sehingga kadar LDL di dalam darah akan meningkat dan akan berdampak pada proses terjadinya penyumbatan pada pembuluh darah koroner. ${ }^{8}$ Kemampuan reseptor akan berkurang seiring dengan bertambahnya usia. Sedangkan LDL reseptor merupakan faktor penghambat (inhibitor) sintesis kolesterol di dalam tubuh, menurunnya aktivitas reseptor LDL akan meningkatkan sintesis kolesterol sehingga kadar kolesterol akan meningkat. ${ }^{9}$ Usia diatas 45 tahun adalah rentang usia yang berisiko untuk menderita hiperkolesterolemia. ${ }^{10} \mathrm{Se}$ hingga penelitian ini tidak sesuai dengan penelitian yang dilakukan Cooper Clinic, USA mengenai hubungan usia dengan profil lemak dalam darah membuktikan bahwa terdapat kenaikan kadar kolesterol pada pria seiring dengan bertambahnya usia seseorang. Hasil dari penelitian Aulia menunjukkan bahwa kadar kolesterol total yang tinggi $(\geq 200 \mathrm{mg} / \mathrm{dl}$ ) lebih banyak di alami pada responden yang lebih tua ( $>45$ tahun) dibandingkan dengan responden dengan usia muda ( $\leq 45$ tahun). ${ }^{11}$

Pola makan tinggi lemak dalam penelitian ini adalah frekuensi responden dalam mengkonsumsi makanan yang tinggi akan kandungan lemak. Makanan tinggi lemak pada penelitian ini meliputi sumber makanan lemak hewani (daging sapi, ayam goreng, daging kambing, ikan mujair, 
jeroan sapi, ayam, telur ayam dan telur bebek), serta produk olahan lainnya (lemak babi, margarine, mentega, gorengan, santan, coklat batang, es krim dan susu). Menggunakan uji statistik chi square diperoleh $p=0,285(p>0,05)$ hal ini menunjukkan bahwa tidak ada hubungan antara pola makan tinggi lemak dengan kadar kolesterol total.

Teori menurut Sastriamidjojo menyebutkan bahwa konsumsi makanan yang tinggi lemak dan kolesterol akan meningkatkan kadar kolesterol total dan kadar LDL. ${ }^{12}$ Hati akan mempunyai cukup kadar kolesterol dan akan menghentikan pengambilan LDL yang dapat meningkatkan kadar kolesterol total. Hasil penelitian Nurrahmani menyatakan orang yang berisiko memiliki kadar kolesterol tinggi adalah mereka yang menerapkan pola makan yang mengandung kadar lemak jenuh yang tinggi. ${ }^{13}$ Lemak jenuh (ditemukan pada daging, mentega, keju dan krim) dapat meningkatkan kadar kolesterol LDL dalam darah.

Penelitian ini sejalan dengan penelitian yang dilakukan Hamiid yang menyatakan bahwa asupan makanan dari lemak tidak berpengaruh pada kadar kolesterol total, HDL rendah merupakan faktor risiko penting yang menyebabkan infark miokard akut dan tidak dipengaruhi oleh asupan lemak dalam makanan. ${ }^{14}$ Hasil penelitian Gayet-Boyer menemukan tidak ada hubungan liniear antara konsumsi lemak trans dengan HDL, LDL dan kadar kolesterol total. ${ }^{15} \mathrm{Hal}$ ini berbeda dengan penelitian Kusuma yang menunjukkan ada hubungan antara pola makan (makanan berlemak) dengan kadar kolesterol total. ${ }^{18}$

Tidak ada hubungan antara pola makan tinggi lemak dengan kadar kolesterol di Puskesmas Mulyorejo bukan berarti pola makan tinggi lemak diabaikan begitu saja. Bedasarkan data dari penelitian, diduga bahwa pola makan tinggi lemak dapat menjadi faktor risiko dari seseorang yang mempunyai kadar kolesterol yang tinggi, karena menurut data penelitian sebagian besar responden yang memiliki kadar kolesterol tinggi mempunyai pola makan tinggi lemak dalam kategori sering yaitu sebanyak 17 responden. Hal ini menunjukkan berarti terdapat kecenderungan bahwa responden yang sering mengkonsumsi makanan berlemak mempunyai kadar kolesterol total yang tinggi.

Pola makan tinggi serat dalam penelitian ini adalah frekuensi responden dalam mengkon- sumsi makanan yang tinggi akan kandungan serat. Makanan tinggi serat pada penelitian ini meliputi sumber makanan kacang-kacangan, sayur-sayuran (wortel, tomat, ketimun, bayam, kangkung, selada, kacang panjang, terong dan daun singkong), serta buah-buahan (pisang, salak, jeruk, apel, pepaya, nanas, mangga). Menggunakan uji statistik chisquare diperoleh $\mathrm{p}=0,030(\mathrm{p}<0,05)$ hal ini menunjukkan terdapat hubungan antara pola makan tinggi serat dengan kadar kolesterol total.

Hasil Penelitian ini sesuai dengan teori dari Sulistijani lactobacillus memfermentasikan serat menjadi asam lemak rantai pendek dan gas, asam lemak rantai pendek mampu mengikat asam empedu sehingga kadar asam empedu menurun. ${ }^{17}$ Berkurangnya asam empedu dapat memperlambat penyerapan lemak sehingga serat berperan dalam penurunan kadar kolesterol dalam darah. Hal ini sejalan dengan penelitian Shreya terdapat hubungan antara asupan serat makanan dengan kadar kolesterol total dan LDL. ${ }^{18}$ Seseorang yang kurang mengkonsumsi serat $(<29$ g/hari) mempunyai risiko $38 \%$ dan $43 \%$ lebih tinggi untuk mengalami hiperkolesterolemia dan mempunyai kadar LDL yang tinggi dibanding dengan yang mengkonsumsi serat (>29 g/hari). Sifat fisiko kimia dari serat mengubah jalur metabolisme kolesterol hati dan metabolisme lipoprotein, yang mengakibatkan penurunan kolesterol LDL plasma. ${ }^{19}$ Hasil dari penelitian Quan Zhoujuga menunjukkan bahwa meningkatnya konsumsi serat akan menurunkan kadar kolesterol total dan LDL. ${ }^{20}$ Bila asupan serat makanan rata-rata meningkat dari $<18 \mathrm{~g} /$ hari menjadi $>30 \mathrm{~g} / \mathrm{hari}$, tingkat kolesterol HDL rata-rata meningkat sebesar $10,1 \%$, sedangkan kadar kolesterol total dan LDL akan menurun sebesar 14,4\% untuk laki-laki dan sebesar $11,1 \%$ untuk perempuan.

\section{KESIMPULAN DAN SARAN}

Hasil dari penelitian mengenai pengaruh pola makan dengan kadar kolesterol total yang dilakukan di Puskesmas Mulyorejo Surabaya dapat disimpulkan bahwa tidak terdapat hubungan antara usia dengan kadar kolesterol total yang ditunjukkan dengan hasil analisis statistik yaitu $p=1$ ( $>0,05)$. Kemudian untuk variabel pola makan tinggi lemak tidak terdapat hubungan antara pola makan tinggi lemak dengan kadar kolesterol to- 
tal yang ditunjukkan dengan hasil analisis yaitu $p=0,285(p>0,05)$. Sedangkan untuk variabel pola makan tinggi serat menunjukkan terdapat hubungan antara pola makan tinggi serat dengan kadar kolesterol total yang ditunjukkan bedasarkan hasil analisis statistik yaitu $\mathrm{p}=0,030 \quad(\mathrm{p}>0,05)$ dengan besar risiko $\mathrm{OR}=4$. Saran bagi responden sebaiknya melakukan pemeriksaan rutin kadar kolesterol total minimal 6 bulan sekali. Sedini mungkin melakukan pengaturan pola makan yang seimbang. Menghimbau masyarakat untuk meningkatkan konsumsi serat. Puskesmas hendaknya memberikan tambahan informasi dan menghimbau kepada masyarakat di wilayah kerja Puskesmas Mulyorejo Surabaya untuk peduli terhadap faktor risiko dari kadar kolesterol total yang meliputi pola makan tinggi lemak, pola makan tinggi serat, dan paparan asap rokok. Hal ini dilakukan karena kadar kolesterol total merupakan faktor risiko dari beberapa penyakit tidak menular seperti jantung koroner dan stroke.

\section{DAFTAR PUSTAKA}

1. WHO. Noncommunicable Disease Country Profiles Geneva: WHO Press; 2011.

2. Kementrian K. Profil Kesehatan Dasar Tahun 2013. Jakarta: Kementrian Kesehatan RI; 2014.

3. Annies. Kolesterol dan Penyakit Jantung Koroner Jogjakarta: Ar-Ruzz Media; 2015.

4. Kemenkes RI. Survei Kesehatan Rumah Tangga. Jakarta: Badan Litbangkes Kemenkes RI; 2004.

5. Khomsan A. Sehat dengan Makanan Berkhasiat Jakarta: PT Kompas Media Nusantara; 2007.

6. Sulastri, Delmi, Rahayuningsih S, Purwantyastuti. Pola Asupan Lemak, Antioksidan, serta Hubungannya dengan profil Lipid pada Laki-laki Etnik Minangkabau. Majalah Kedokteran Indonesia. 2005; 55.

7. Sastroasmoro $\mathrm{S}$, Ismael L. Dasar-Dasar Metode Penelitian Klinis. Jakarta: Binarupa Askara; 1995.

8. Soeharto I. Pencegahan dan Penyumbatan Penyakit Jantung Koroner Jakarta: PT Gramedia Pustaka Utama; 2002.

9. Murray R, Granner D, Mayes P\&R. Biokimia Herper. Jakarta: Penerbit Buku Kedokteran
ECG; 2000.

10. Sayeed M. Prevalence and Risk Factor of Coronary Heart Disease In Rural Population of Bagladesh. Ibrahim Med Coll J. 2004; 4.

11. Aulia A. Hubungan Pola Konsumsi Makan, Status Gizi, Stress Kerja dan Faktor Lain dengan Hiperkolesterolemia pada Karyawan PT Semen Padang Tahun 2012. Jakarta: Universitas Indonesia, Gizi Kesehatan Masyarakat; 2012.

12. Sastromidjodjo. Peganga Penatalaksana Nutrisi Pasien Jakarta: Binarupa Askara; 2000.

13. Nurrahmani U. Stop! Kolesterol Tinggi. Jogjakarta: Group Relasi Inti Media; 2012.

14. Hamiid M, Abdul R, Rehan R, Nadeem HM. Relation of Cholesterol Level to Dietary Fat Intake in Patients of Ischemic Heart disease. Cardiovascular Pharmacology. 2015; 4.

15. Gayet B, Tenenhaus A, Prunent C. Is There Linier Realtionship Betwee Dose of Ruminant Trans-Fatty Acid and Cadiovascular Risk Markers in healthy Subject: Resul Froma Systemaic review and Meta-Reression of Randomised Clinical trial. British Journals of Nutritions. 2014; 112.

16. Ira M. Hubungan Pola Makan dengan Peningkatan Kadar Kolesterol Pada Lansiadi Jebres Surakarta. Jurnal Keperawatan 17 Surakarta. 2014.

17. Sulistijani D. Sehat dengan Men Berserat. Jakarta: Trubus Agriwidya; 2002.

18. Shreya N, Nagarajan L, Ruch V, Mookambika R, Vasudevan S, Kamala K, et al. Association of Dietary Fiber Intake with Serum Total Cholesterol and Low Density Lipoproein Cholesterol Levels in Urban Asia-Indian Adults with Type 2 Diabetes. Indian Journal of Endocrinology and Metabolism. 20014 Sempetmber-October; 18.

19. Fernandez M. Soluble Fiber and NonDisgestible Carbohydrate Effect On Plasma Lipid and Cardiovascular Risk. Curr Opin Lipidol. ; 12.

20. Zhou Q, Jiang W, Jie T, Jia-Ji W, Chu-Hong L, Pei-Xi W. Benefical Effect of Higher Dietary Fiber Intake on Plasma HDL-C and TC/ HDL-C Ratio among Chinese Rural-to-Urban Migrant Workers. International Journal of Environtmental Research and Public Health. $2015 ; 12$. 